\title{
Farklı Turizm Eğitim Sistemlerinde Yetişen Öğretmenlerin Mesleki Öz-Yeterlik İnançlarının İncelenmesi*
}

Analysis of Occupational Self-Efficacy Beliefs of Teachers Trained in Various Tourism-based Education Systems

\author{
Azize HASSAN**, Feriyal FARHADi*** \\ ** *Prof. Dr., Ankara Hacı Bayram Veli Üniversitesi Turizm Fakültesi, 06830 Gölbaşı, Ankara. \\ E-posta: azize.hassan@hbv.edu.tr \\ ORCID: 0000-0003-2509-1415 \\ ***Doktora Öğrencisi, Gazi Üniversitesi Sosyal Bilimler Enstitüsü, 06500 Emniyet Yenimahalle, Ankara. \\ E-posta: feriyalfarhadi@hotmail.com \\ ORCID: 0000-0001-6425-6038
}

MAKALE BILGILERI

Makale işlem bilgileri:

Gönderilme tarihi: 14 Nisan 2019

Düzeltme: 20 Mayıs 2019

Kabul: 20 Eylül 2019

Anahtar sözcükler: Turizm eğitimi, Ĕ̆itim sistemi, Pedagojik formasyon, Öz-yeterlik.

ARTICLE INFO

Article history:

Submitted: 14 April 2019

Resubmitted: 20 May 2019

Accepted: 20 September 2019

Key words: Tourism education, Education system, Pedagogical formation, Self-efficacy.

\section{ÖZ}

Bilindiği üzere, Yüksek Öğretim Kurumu'nun teklifi, Millî Eğitim Bakanlığı'nın 28.9.2009 tarihli ve 25377 sayılı yazısı üzerine, 28.3.1983 tarihli ve 2809 sayılı Kanun'un ek 30 uncu maddesine göre, Bakanlar Kurulu'nca mesleki ve teknik eğitim fakültelerinin kapatılması 02.11.2009 tarihinde kararlaștırılmıștır. Öğretmen olmak isteyen lisans öğretcileri eğitim fakültelerinden pedagojik formasyon dersleri alabilmektedirler. Bu çalışmada söz konusu değişimle, yeni turizm eğitim sisteminden mezun olan öğretmenler ile değişim öncesi mezun olmuş öğretmenlerin mesleki öz-yeterlik inançlarının düzeyleri araştırılmıştır. Araştırmada; nicel araştırma yöntemlerinden alan araștırması uygulanmıș, veriler gayeli örnekleme yöntemiyle anket kullanılarak toplanmıştır. Mesleki öz-yeterlik inançlarının tespiti için öğrenci katıımına, öğretim stratejilerine ve sınıf yönetimine yönelik öz-yeterlikleri ölçen üç boyutlu öğretmen Öz-yeterlik Ölçeği kullanılmıştır. Genel olarak, her iki grubun mesleki öz-yeterlik inanç düzeylerinin oldukça yeterli olduğu ve demografik değişkenlere göre mesleki öz-yeterlik inançlarında anlamlı bir farklılaşmanın olmadığı görülmüştür.

\begin{abstract}
As known, the foreclosure of the vocational and technical education faculties was decided by the Council of Ministers on 2.11.2009 according to the Article 30 of the Law No. 2809 dated 28.3.1983, upon the proposal of the Higher Education Institution and letter of the Ministry of National Education dated 28.9.2009 and numbered 25377. Undergraduate students who would like to be instructors are able to take pedagogical formation lessons. This study examines the differences between the levels of professional self-efficacy beliefs of the teachers who were graduated after the new tourism education system and those who were graduated before the new system. The study employs quantitative research methods and perfoms data collection through a survey with the purposeful sampling method. In order to determine the levels of professional self-efficacy beliefs, a three-dimensional Teacher Self-Efficacy Scale was used to measure the self-efficacy with respect to students' participation, teaching strategies and classroom management. In general, the professional self-efficacy belief levels of both groups are quite sufficient and that there is no significant difference in the professional self-efficacy beliefs according to the demographic variables.
\end{abstract}

\section{GiRiş}

Birleşmiş Milletler Dünya Turizm Örgütü'nün 2017 y1lı turizm raporuna göre; Türkiye, turizm geliri açısından ilk 10'a girmemiş olsa da 37,5 milyon ziyaretçi sayısı ile dünyada 8 'inci sıraya yük-

* Bu çalışma, Dokuz Eylül Üniversitesi Foça Turizm Fakültesi ile Anatolia Turizm Akademisi tarafından 11-14 Ekim 2018 tarihlerinde Foça'da düzenlenen "Hasan Olalı Turizm Sempozyumu"nda sunulmuş halinin, yazarlarca daha sonra geliştirilerek, yeniden düzenlenmiş halidir. selmiştir. Danışmanlık ve denetim şirketi EY'nin hazırladığı Turizm Sektörü Değerlendirmesi raporuna göre; turizm sektörünün gayrisafi milli hasılasına doğrudan katkısı 2017 yılında 26,1 milyar dolar seviyesinde iken, 2018 yılında 36,3 milyar dolara ulaşması beklenmektedir (TÜROB 2018). Turizm hizmet sektörünün ekonomiye her anlamda doğrudan önemli katkısı sebebiyle, sektörde büyük oranda kalifiye elemana gereksinim bulunmaktadır. Bu nedenle, onları yetiştiren öğ- 
retmenlerin gelişmelere ayak uyduran, iyi yetiştirilmiş kişiler olmaları, kalifiye personel yetiştirmeleri bağlamında oldukça önemlidir.

1965 yılında turizmin ülke için önemli bir gelir kaynağı olacağı fark edilerek, turizm bölümünün eklenmesiyle, dört yıllık lisans eğitimi haline dönüştürülen Ticaret Turizm Yüksek Öğretmen Okulu turizm sektörüne ilk eleman yetiştiren eğitim kurumu olmuştur.

Turizm eğitim sisteminde nitelikli öğretmen yetiştirmede, farklı zamanlarda değişik programların uygulandığı görülebilir. Bakanlar Kurulu kararınca 02.11.2009 tarihinde mesleki ve teknik eğitim fakülteleri kapatılıncaya kadar (Resmî Gazete 2009), ticaret ve turizm eğitim fakülteleri ve mesleki eğitim fakülteleri tarafından sektöre kalifiye alt ve orta düzey personel ile söz konusu personeli yetiştiren ortaöğrenim okullarına öğretmen yetiştirilmekteydi. Daha sonra ilgili fakültelerin pedagojik formasyon dersleri ayrılarak eğitim fakültelerine verilmiş, lisans öğrencileri öğretmen olmak istemeleri halinde; lisans eğitimlerini sürdürürken, diğer taraftan da eğitim fakültelerinden pedagojik formasyon derslerini almaktaydılar. Söz konusu farklılık sonucu mevcut ortamda, farklı turizm eğitim sistemlerinden mezun öğretmenlerin görev yaptığ 1 görülmektedir.

Öğretmenlerin, öğrencilerin başarılı olma düzeylerini olumlu yönde etkileyen nitelikleri ve mesleki özelikleri incelediğinde; mesleklerine ilişkin yeterli düzeyde inanca sahip oldukları görülebilir. Bir öğretmenin mesleki öz-yeterlik inanç düzeyi yüksek olduğunda, eğitim verdiği süreçte etkili stratejiler seçebilir, öğrenci katılım düzeyini artırabilir ve aktif bir sınıf yönetimi uygulayabilir.

Türkiye'nin yeni turizm eğitim sistemine göre; pedagojik eğitim ayrı olarak verilmektedir. Bu yüzden yeni sistemle yetişen öğretmenlerin mesleki öz-yeterlik inanç düzeyleri merak konusu olmaktadır. Çalışmanın temel amacı; yeni turizm eğitim sisteminde uygulanan pedagojik formasyon eğitiminin, turizm öğretmenlerine sağladığ1 mesleki öz-yeterlik inanç düzeylerini belirlemektir. Ayrıca, pedagojik formasyon eğitimini ayrı olarak alan turizm öğretmenleri ile eski eğitim sisteminden mezun olan turizm öğretmenlerinin mesleki öz-yeterlik inanç düzeylerinin demografik özelliklerine göre karşılaştırılması amaçlanmiştır.

Araştırma, bir örnek olay çalışması olduğu için elde edilecek veriler, yeni turizm eğitim sistemi hakkında fikir yürütme olanağı sağlayabilir. Mesleki öz-yeterlik düzeyinin tespiti; turizm bölümlerinde eğitim alan öğretmen adaylarının nitelikli olarak yetiştirilmesi için yararlı ipuçları verebileceği düşünülmektedir. Bu sonuçlar eşliğinde getirilen öneriler, Türkiye'deki sürdürülebilir turizmin kalkınması ve geliştirilmesi için yararlı politikaların gerçekleştirilmesine katkı sağlayacağ 1 düşünülmektedir.

\section{ALANYAZIN TARAMASI}

Turizm eğitim sistemi, sektöre eleman yetiştirme olanağı sağlamakla birlikte, öğretmen yetiştirme görevini de üstlenmektedir. Lisans düzeyinde yetişen öğretmenler, turizm okullarında eğitim alan öğrencilerin; bilgili, donanımlı ve yetenekli olmalarını sağlayarak, turizm sektöründe ihtiyaç duyulan kaliteli elemanları kazandırmaktadırlar. Turizm sektörünü oluşturan birimlerin, fiziksel yapıları kadar bunlara anlam kazandıran nitelikli insan gücünün çalıştırılması da büyük öneme sahip olabilmektedir. Turizm eğitim sisteminde hazırlanan planların ve uygulanan stratejilerin kalitesi, hem eğitim veren öğretmenlerin hem de eğitim alan öğrencilerin nitelik düzeylerini doğrudan etkileyebilmektedir.

Hasan Olalı, akademik turizm eğitiminin kurumsallaşmasının, turizm araştırmalarının ve turizm alanyazının gelişimi için yapmış olduğu faaliyetlerle Türkiye'de bu alanın gelişimine öncülük edenlerden birisi olmuştur (Kozak 2000). Olalı, turizm eğitimini gerektiren birçok nedene değinerek, turizm eğitiminin tanımını şu şekilde yapmıştır: Turizm eğitimi; turizm sektöründe verimliliği artırmak, hizmeti sunan kişilerin yeteneklerini ve insancıl özelliklerini geliştirmek için verilen bir eğitimdir (Olalı 1982).

Turizm eğitimi teorik bilgilerle, pratik uygulamaların harmanlanmasını sağlamaktadır. Turizm eğitimi sektörün gelişmesine katkıda bulunmakla birlikte, kalifiye personelin yetişmesi- 
ne yardımcı olmaktadır. Turizm faaliyetlerinin ülke ekonomisinin kalkınmasına yaptığı önemli desteğin fark edilmesi ve vatandaşlarda olumlu bir turizm bilinci oluşturma çabası, bu alanda verilen eğitimle gerçekleştirilmektedir. Turizm eğitimi vasıtasıyla; bu sektörde çalışanların bilgileri ve becerileri artırılmış olmakta ve insanların ilgilerini turizme çekebilmek mümkün hale gelebilmektedir. Turizm eğitiminin en önemli amaçlarından biri de nitelikli öğretmenlerin yetiştirilmesidir (Hacıoğlu vd. 2008)

Yükseköğretim düzeyinde turizm eğitimine Türkiye'de ilk olarak Ankara Ticaret Yüksek Öğretmen Okulu'na 1965-66 öğretim yılında Turizm Bölümü ilave edilerek başlanmıştır. Ardından Ege Üniversitesinde 1969, Hacettepe Üniversitesi 1974, Bursa İktisadi ve Ticari İlimler Akademisi 1975, Adana İktisadi ve Ticari İlimler Akademisi 1980 ve Erciyes Üniversitesi bünyesinde 1982 yılında önlisans ve lisans düzeyinde turizm eğitimi veren birimler kurulmuştur. YÖK'ün teklifi ve Milli Eğitim Bakanlığı tarafından 13.11.2009 tarihi itibariyle de Turizm Fakülteleri açılmıştır (Resmî Gazete 2009).

Planlı ve nitelikli öğretmen yetiştirmek için gerçekleştirilen yenilikler doğrultusunda özellikle öğretmenlerin ihtiyaç ve istihdamlarına yönelik alınan bazı kararlar ve uygulamalar Türkiye'de öğretmen yetiştirme sisteminin problemleri olarak günümüzde de tartışma konusu olmayı sürdürmektedir. Son dönemde tartışlan uygulamalardan biri de Pedagojik Formasyon Eğitimi Sertifika Programi'na katılarak, eğitim fakültesi dışındaki diğer fakülte mezunlarının öğretmen olma hakkını kazanmasıdır (Gurol vd. 2018).

Pedagojik formasyon eğitimi programın uygulanmasındaki temel amaç, öğretmen adaylarına öğretmenlik becerisini kazandırmaktır. Öğretmenlik meslek dersleri olarak da adlandırılabilir (Binbaşığlu 1995). Pedagojik formasyon eğitim programı; öğrencinin eğitilmesi, sınıf yönetimi, ders planı geliştirme ve uygulama ile öğrenci değerlendirmesi gibi tüm konularda öğretmenlik becerisini geliştirebilen bir bilgilendirme biçimidir. Özetle pedagojik formasyon, öğretmen olabilmek için alınması gereken bir eğitim programidır (Shulman 1986; Mishra ve Koehler 2006).
Ülkelerde öğretmen yetiştirme sistemini daha iyi yerlere getirebilmek için pedagojik formasyon eğitiminin sisteme yerleştirildiği görülmektedir (Yıldırım ve Vural 2014).

Türkiye eğitim sisteminde uzun yıllardır tartışılan nitelikli öğretmen yetiştirme ve öğretmen istihdamı; Yüksek Öğretim Kurulu'nu, Milli Eğitim Bakanlığını, üniversiteleri ve eğitimcileri çeşitli model arayışlarına yönlendirmektedir. Özellikle 1970 yılından itibaren nitelikli öğretmen yetiştirme ve etkin pedagojik formasyon programı hazırlanma çabasının günümüze kadar sürdüğü görülmektedir (Abazoğlu vd. 2016).

Eğitim alanında görev üstlenen her birey; öğrenci, öğretmen adayı veya öğretmen, başarılı olabilmek için ‘üstlendiğim görevi gerçekleştirebilmek için gereken düşünceleri ve eylemleri ne kadar uygulayabiliyorum?' sorusunu kendine sormalıdır (Goddard vd. 2004). Aslinda birey bu soruyla öz-yeterlik inancını sorgulamış olmaktadır. Öz-yeterlik algısının ve inancının oluşması için eğitim sürecinde bireyin aldığ 1 teorik dersler ve pratik uygulamalar önemlidir. Ders müfredatında öz-yeterlik inancının gelişmesiyle ilgili yerleştirilen programlar bireyin bu konuda gelişmesini sağlamakta etkin rol oynamaktadır (Bandura 1977; 1982).

Kişisel deneyimler, başkalarının deneyimlerinden çıkarılan sonuçlara dayanan dolaylı deneyimler, toplumsal onay ve bireyin fizyolojik ve duygusal durumuyla ilgili etmenler öz-yeterlik inancının oluşmasında etkili rolü bulunmaktadır (Bandura 1995).

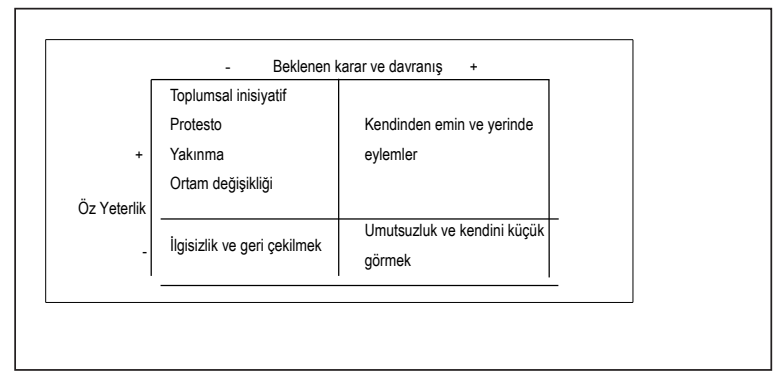

Şekil 1. Öz-yeterlik inancının düzeyi ve beklenen kararın bir fonksiyonu olarak bireyde oluşan davranışsal ve duygusal tepki türleri (Bandura 1982). 
Şekil 1'de öz-yeterlik inancının düzeyiyle, beklenen kararı ilişkilendirerek, bireyde bir fonksiyon olarak, davranışsal ve duygusal tepkileri açıklanmıştır (Bandura 1982):

Pedagojik formasyon eğitimi sertifika programına katılmayı planlamanın hedeflerden biri; aday öğretmenlerin, mesleki niteliklere sahip olmakla birlikte, mesleğe ilişkin kişisel özeliklerini de geliştirmek istemesidir. Bu bağlamda turizm branşlarındaki aday öğretmenlerin ayrı olarak eğitim almış oldukları pedagojik formasyon eğitiminden elde ettikleri mesleki öz- yeterlik inanç düzeyleri de merak konusu olmuştur.

\section{ILGILI ÇALIȘMALAR}

Kırıkkale Üniversitesi Eğitim Fakültesi Sınıf Öğretmenliği Programı'nda öğrenim gören son sınıf öğrencileri ile aynı üniversitede formasyon eğitimi alan Fen Edebiyat Fakültesi öğrencilerinden oluşan toplam 338 kişi üzerinden bir araştırma yürütülmüştür. Katılımcıların mesleki öz-yeterlik inanç düzeylerini tespit etmek için Çapa ve arkadaşlarının (2005) Türkiye'de uyguladıkları mesleki öz-yeterlik ölçeğini kullanmışlardır (Elkatmış vd. 2013). Araştırma sonuçlarına göre; her iki öğrenim grubundaki öğrencilerin öğretmenlik mesleğine ilişkin aynı düzeyde özyeterlik inancına sahip oldukları bulunmuştur. Böylelikle araştırmada Eğitim Fakültesi öğrencileri ile formasyon eğitimi alan Fen Edebiyat Fakültesi öğrencilerinin fakülte farkı, mesleki öz-yeterlik inançlarını etkilememiş olduğu tespit edilmiştir. Ancak, Eğitim Fakültesi öğrencilerinin mesleki öz-yeterlik puan ortalamalarının cinsiyete göre farklılık gösterdiği ortaya çıkmıştır. Erkek katılımcıların mesleki öz-yeterlik inanç düzeylerinin, kız katılımcılarına göre daha yüksek olduğu görülmüştür.

Mersin Üniversitesi Eğitim Fakültesi pedagojik formasyon programına kayıt yaptıran öğrencilere yönelik yürütülen bir araştırmaya, 381 gönüllü katılımcıdan yanıt gelmiştir ve elde edilen veriler analize tabi tutulmuştur. Çalışmada Çapa vd. (2005) tarafından Türkçeye uyarlanan mesleki öz-yeterlik ölçeği kullanılmıştır. Matematik-Fen Bilimleri Bölümü adı altında Edebiyat Programı'ndan 144 ve Matema- tik Programı'ndan 86 öğrenci araştırmaya katılmıştır. Sosyal Bilimler adı altında İngilizce Programı'ndan 52, Kimya Programı'ndan 28, Biyoloji Programı'ndan 24, Tarih Programı'ndan 27, Felsefe ve Sosyoloji Programı'ndan 25 ve Tak1 Tasarımı Programı'ndan 13 öğrenci ankete yanıt vermiştir (Çocuk vd. 2015).

Araştırmadan elde edilen verilere göre; pedagojik formasyon eğitimi alan öğretmen adaylarının öğretmen öz-yeterlik inanç düzeyi yüksek çıkmıştır. Katılımcıların mesleki öz-yeterlik inanç düzeyleri, cinsiyete ve yaşa göre anlamlı bir farklılık göstermemiştir. Ancak, eğitim aldıkları bölümlere göre anlamlı bir farklılığın olduğu ortaya çıkmıştır. Ayrıca araştırmada, pedagojik formasyon eğitimi alan öğrencilerin özyeterliklerinde, öğrenim gördükleri bölümler belirleyici bir değişken olarak ortaya çıkmıştır. Sosyal bilimler bölümlerinde eğitim alan katılımcıların öz-yeterlik düzeylerinin, Matematik-Fen bölümlerinde eğitim alan katılımclara göre daha yüksek olduğu görülmektedir. Araştırmacılar, bunun sonucunu; sosyal bilimlerin doğası gereği, psikoloji, sosyoloji ve felsefe alanlarıyla yakından ilişkili ve disiplinler arası bir anlayışın varlığına bağlamışlardır.

Karadeniz Teknik Üniversitesi Fatih Eğitim Fakültesi'nde pedagojik formasyon eğitimi alan 425 aday öğretmen ve Eğitim Fakültesi son sınıf öğrencisi 252 kişi üzerinde bir araştırma gerçekleşmiştir. Araştırmacılar, pedagojik formasyon eğitimi alan 425 aday öğretmenin eğitim aldıkları bölümlere ilişkin açıklamada bulunmamışlardır. Araştırmada iki grubun, öğretmenlik mesleğine yönelik tutumları, öz-yeterlik inançları ve mesleğe yönelik kaygı düzeyleri karşılaştırılmıştır. Katılımcıların mesleki öz-yeterlik inançlarını ölçmek için Çapa ve arkadaşlarının (2005) Türkçeye uyarladıkları ölçek kullanılmıştır (Dadandı vd. 2016). Elde edilen sonuçlara göre; öğretmen adaylarının mesleki öz-yeterlik inançları ve öğretmenliğe yönelik tutumları açısından, iki grup arasında anlamlı bir farklılığa rastlanmamıştır. Ancak, Eğitim Fakültesi öğrencilerinin mesleki kaygı düzeyleri, pedagojik formasyon eğitimi alan öğretmen adaylarından daha yüksek çıktığ 1 tespit edilmiştir. 
Abant İzzet Baysal Úniversitesi Eğitim Fakültesi'nde; pedagojik formasyon eğitimi alan öğrencilerden, Psikoloji Programı'ndan 8 ve Matematik Programı'ndan 117 öğrenci araştırmaya katılmıştır. Ayrıca bu araştırmaya, Tarih Programı'ndan 52, Fizik Programı'ndan 31, Din Kültür ve Ahlâk Programı'ndan 18, Edebiyat Programı'ndan 99 öğrenci dâhil edilmiştir. Buna ilaveten Biyoloji Programı'ndan 54, Kimya Programı'ndan 35, Sağlık Programı'ndan 93, Sosyoloji Programı'ndan 16, Mühendislik Programı'ndan 44, Beden Eğitimi ve Spor Programı'ndan 90 öğrenci araştırmaya katılmıştır.

Söz konusu araştırmaya İktisadi ve İdari Bilimler Fakültesi'nden ise 68 öğrencinin katılımı sağlanmıştır. Diğer bölümler adı altında tanımlanan “Turizm İşletmeciliği ve Otelcilik, Seramik, Halkla İlişkiler ve Tanıtım, Çocuk Gelişimi, Gastronomi" programlarından 29 öğrencinin mesleki öz-yeterlik düzeyleri sorgulanmıştır. Bu araştırmada, 725 öğrencinin mesleki öz-yeterlik düzeylerini ölçmek için Çapa ve arkadaşları (2005) tarafından Türkçeye uyarlanan ölçek kullanılmıştır (Bakaç ve Özen 2017).

Söz konusu araştırma sonucunda pedagojik formasyon öğrencilerinin öğretmenlik mesleğine yönelik öz-yeterlik düzeyleri cinsiyete göre farklılaşmadığı tespit edilmiştir. Ancak, farklı bölümlerde öğretmenlik mesleğine yönelik olarak verilen eğitimin, katılımcıların öz-yeterliklerini farklı düzeylerde etkilediği ortaya çıkmıştır. Öğretim stratejileri ve sınıf yönetimi alt boyutlarında Din Kültürü, Edebiyat, Kimya, Sağlık, İBFF ve BES bölümleri katılımcılarının öğretmenlik mesleğine yönelik öz-yeterlik inanç düzeylerinin, Matematik, Tarih, Biyoloji, Sosyoloji ve Mühendislik bölümü katılımcılarından yüksek çıktığ1 görülmüştür. Ölçeğin öğrenci katılımı boyutunda ise Fizik ve diğer bölümlerden katılımcıların öğretmenlik mesleğine yönelik öz-yeterlik inanç düzeyleri, Mühendislik bölümünden katılanlara göre yüksek çıkmıştır. Araştırma kapsamında pedagojik formasyon öğrencilerinin öğretmenlik mesleğine yönelik tutum puanlarının cinsiyete göre farklllık göstermediği tespit edilmiştir.

Pedagojik formasyon eğitimi konusunu ele alan ve lise öğretmenleri üzerinde bu eğitimin etkilerini araştıran çalışmalara rastlanmıştır. Örneğin; bir araştırma Ankara'da bulunan bir lisede 14 hafta süren staj programına katılmış olan fark11 lisans programlarından oluşan 20 öğretmen adayının üzerinde gerçekleşmiştir. Katılımcıların eğitim aldıkları bölümler; Felsefe (1), Sosyoloji (1), İngilizce Dili ve Edebiyatı (2), Tarih (1), Matematik (1), Türk Dili ve Edebiyatı (3), Spor Yönetimi (3), Antrenörlük (2) ve Rekreasyon (4) olmak üzere dokuz eğitim alanından oluşmuştur (Filiz ve Duranli, 2019).

Görüşme tekniğiyle gerçekleşen söz konusu araştırmadan elde edilen bilgilere göre; pedagojik formasyon eğitimi kapsamında verilen teorik derslerin azaltılması ve bunun yerine uygulamalı derslerin artıılmasının daha faydalı olacağı kanaatine varılmıştır. Ayrıca, öğretmenlik yeterliliklerinin geliştirilmesine yönelik alınan derslerin içeriklerine ağırlık verilmesi gerektiği de vurgulanmiştır.

Eğitim Fakültesi formasyon öğrencilerinin mesleğe yönelik öz-yeterlik inançlarının düzeyini ölçmekle birlikte mesleki öz-yeterlik inançları ile mesleki kaygıları arasındaki ilişki yönünü tespit eden güncel araştırmalara da rastlanabilir. Örneğin, Pamukkale Üniversitesi Eğitim Fakültesinde, Pedagojik Formasyon Eğitimi Sertifika Programı'nda öğrenim gören 254 öğretmen adayının katılımıyla bir araştırma gerçekleştirilmiştir. Araştırmacılar Dellinger vd. (2008) tarafından geliştirilen, Taşkın ve Hacıömeroğlu'nun (2010) Türkçeye uyarladığı öz-yeterlik ölçeğini çalışmalarında kullanmışlardır. Ancak, araştırmacılar katılımcıların eğitim gördükleri bölümler hakkında açılamada bulunmamışlardır (Kahraman ve Çelik 2019).

Sözü geçen araştırmada; katılımcıların mesleki öz-yeterlik inanç düzeyleri yüksek çıkmıştır. Ayrıca, planlama ve öğrenmeyi geliştirme, olumlu sınıf ortamı oluşturma, etkili öğrenme-öğretme süreci, bireysel farklılıklar ve akademik olarak dört alt boyutun değerleri yüksek bulunmuştur. Bununla birlikte katılımcıların öz- yeterlik inanç düzeyleri, cinsiyetlerine göre anlamlı farklılık göstermemiștir. 


\section{YÖNTEM}

Araştırmada, eski ve yeni turizm eğitim sisteminde yetişen öğretmenlerin mesleki öz-yeterlik inançlarının düzeylerini incelemek için anket tekniği kullanılmıştır. Bunun için, Google Documents Arar acılığıyla anketler oluşturulmuş ve Facebook/e-posta aracılığıyla turizm öğretmenlerine uygulanmıştır. İki bölümden oluşan anketin ilk bölümünde katılımcıların; cinsiyet, yaş, eğitim aldıkları sistem ve öğretmenlik yaptıkları süreye ilişkin demografik bilgilere yer verilirken, ikinci bölümünde 24 maddeden oluşan mesleki öz-yeterlik inanç ölçeği bulunmaktadır. Ankete, Ağustos 2018-Aralık 2018 dönemleri arasında 103 öğretmen katılmıştır.

Katılımcıların öz-yeterlik inanç düzeylerini belirlemek için, orijinali Tschannen-Moran ve Hoy (2001) tarafından hazırlanan ve Türkçeye uyarlaması Çapa vd. (2005) tarafından gerçekleştirilen Öğretmen Öz-Yeterlik Ölçeği kullanılmıştır.

Bir ölçeğin farklı bir dilden uyarlanıyor olması, çevirinin olabildiğince aslına uygun olmasının yanında, uyarlanacak olan ölçeğin kullanılacak olan bölge ya da topluma kültürel olarak da uygun olması gerekmektedir. Bunun için uyarlanan ölçek, pratiğe döküldügüunde aslına uyumlu özelliklerini ve standartlarını taşımalıdır (Erkuş 2007).

Literatür taramasında öğretmen adaylarının ve öğretmenlerin mesleki öz-yeterlik inanç düzeylerini ölçmek için Çapa vd. (2005) Türkçe diline uyardıkları ölçeğin, sıklıkla araştırmalarda kullanıldığı görülmektedir. Ölçek, öğrenci katılımına, öğretim stratejilerine, sınıf yönetimine yönelik öz-yeterlik inançlarını belirleyen üç boyuttan oluşmaktadır. Ölçeğin Türkçe uyarlamasında bu boyutlar için Cronbach Alfa güvenirlik katsayıları sirasiyla $0,82,0,86$ ve 0,84 olarak elde edilmiş ve ölçeğin tamamına ilişkin güvenirlik ise 0,90 olarak bulunmuştur. Ölçeğin yapı geçerliliği için uygulanan doğrulayıcı faktör analizinde model uyum indeksleri $\mathrm{CFI}=0,99$, TLI= 0,99 ve RMSEA = 0,65 olarak hesaplanmıştır. Her bir boyutta 8'er maddenin bulunduğu toplam 24 maddelik ölçek 1- Yetersiz ve 9- Çok Yeterli cevabına karşılık gelmek üzere 9-lu Likert tipinde hazırlanmıştır. Dolayısıyla her bir boyut ortalaması
40 olmak üzere en düşük 8 ve en yüksek 72 puan alabilmektedir. Ölçeğin toplam puanı yüksek çıktığında, katılımcıların öz-yeterlik inançlarının da yüksek olduğu anlamına gelmektedir.

Ölçekte, öğrenci katılımına yönelik öz-yeterlik inanç boyutunu 1, 2, 4, 6, 9, 12, 14, 22; öğretim stratejilerine yönelik öz-yeterlik inanç boyutunu ise $7,10,11,17,18,20,23,24$ ifadeleri ölçmektedir. Ayrıca, sınıf yönetimine yönelik öz-yeterlik inanç boyutunu ölçebilmek için 3, 5, 8, 13, 15, 16, 19, 21 ifadelerine yer verilmiştir (Çapa vd. 2005).

$\mathrm{Bu}$ araştırma için toplanan verilerin dağ ${ }_{1}$ 1- $^{-}$ mı Kolmogorov-Smirnov testi ile incelenmiş ve normal dağılıma uyduğu görülmüştür. Bu nedenle, araştırmada parametrik testler tercih edilmiştir. Mezun olunan eğitim sistemi, cinsiyet ve yaş grubu iki düzeyli olduğu için bu değişkenlere ilişkin karşılaştırmalarda bağımsız gruplarda t-testi, hizmet süresi üç düzeyli olduğu için bu değişkene ilişkin karşılaştırmada ise tek yönlü varyans analizi (ANOVA) kullanılmıştır. Çalışmada homojen varyans varsayımı Levene testi ile incelenmiştir. Analizler IBM SPSS v20 kullanılarak yapılmış ve anlamlılık düzeyi için üst sınır 0,05 olarak alınmıştır.

\section{BULGULAR}

Bu bölümde, eski eğitim sisteminden mezun olan turizm öğretmenleriyle, yeni sistemden mezun olan öğretmenlerin mesleki öz-yeterlik inançları karşılaştırılmıştır. Bununla birlikte iki sistemden oluşan katılımcı grupların demografik özelliklerine göre de karşılaştırma yapılmış ve sonuçlar Tablo 1 ve Tablo 4 ile verilmiştir.

Tablo 1'deki veriler dikkate alındı ğında katılımcıların mesleki öz-yeterlik inançlarının mezun oldukları turizm eğitim sistemine göre anlamlı bir farklılık göstermediği söylenebilir $(p<0,05)$. Yani, katılımcıların mezun oldukları turizm eğitim sistemi, mesleki öz-yeterlik inançları üzerinde önemli bir etkiye sahip değildir. Bununla birlikte, ortalama değerler dikkate alındı̆̆ında öğrenci katılımı, öğretim stratejileri ve sınıf yönetimi boyutları için mesleki öz-yeterlik inançları hem eski turizm eğitim sistemi hem de yeni turizm eğitim sistemi için oldukça yeterli düzeyinde olduğu söylenebilir. Elde edilen verilere göre, es- 
Farklı Turizm Eğitim Sistemlerinde Yetişen Öğretmenlerin Mesleki Öz-Yeterlik İnançlarının İncelenmesi

Tablo 1. Öz-Yeterlik İnançlarının Mezun Olunan Turizm Eğitim Sistemine Göre Karşılaştırılması

\begin{tabular}{llllll}
\hline Öz yeterlik & Mezun olunan Turizm Eğitim Sistemi & $N$ & Ortalama & Standart sapma & $t$ \\
\hline \multirow{2}{*}{ Öğrenci katılımı } & Yeni Turizm Eğitim Sistemi & 46 & 52,24 & 10.472 & .771 \\
\cline { 2 - 5 } & Eski Turizm Eğitim Sistemi & 57 & 50,18 & 16.510 \\
\hline Öğretim stratejileri & Yeni Turizm Eğitim Sistemi & 46 & 54,33 & 11.412 & .028 \\
\cline { 2 - 5 } & Eski Turizm Eğitim Sistemi & 57 & 54,25 & 17.512 \\
\hline Sınıf yönetimi & Yeni Turizm Eğitim Sistemi & 46 & 52,74 & 11.440 & -.255 \\
\cline { 2 - 5 } & Eski Turizm Eğitim Sistemi & 57 & 53,47 & 17.662 & .172 \\
\cline { 2 - 5 } & Yeni Turizm Eğitim Sistemi & 46 & 159,30 & 31.484 \\
\hline
\end{tabular}

ki ve yeni eğitim sistemine göre pedagojik eğitimini ayrı alan ve almayan turizm öğretmenlerinin mesleki öz-yeterlik inanç düzeylerinde farklılık görünmemektedir. Elkatmış vd. (2013) ile Dadandı vd.'nin (2016) yaptıkları çalışmalardan elde ettikleri sonuçlar ile tablo 1'deki sonuçlar arasında benzerlik görülmektedir.

Analizlerde eski ve yeni turizm eğitim sisteminde yetişen iki grubun mesleki öz-yeterlik inanç düzeyleri arasında anlamlı bir farklılık çıkmadığ yerine demografik değişkenler açısından incelemelerine yer verilmiştir.

Tablo 2'deki veriler incelendiğinde katılımc1ların mesleki öz-yeterlik inançlarının cinsiyetlerine göre anlamlı bir farklılık göstermediği söylenebilir $(p<0,05)$. Yani, katılımcıların cinsiyetleri mesleki öz-yeterlik inanç düzeylerinde önemli bir etkiye sahip değildir. Bununla birlikte, ortalama değerler dikkate alındığında öğrenci katılımı, öğretim stratejileri ve sınıf yönetimi boyutları için mesleki öz-yeterlik inancının hem erkek hem de kadın katılımcılarda oldukça yeterli düzeyinde olduğu söylenebilir. Demirtaş vd. (2011) yaptıkları araştırmada, öğretmen adaylarının mesleki öz-yeterlik inanç düzeyini ölçmek için Çapa vd. (2005) mesleki öz-yeterlik ölçeğini kullanmışlardı ve elde ettikleri sonuçlara göre; öğretmen adaylarının mesleki öz-yeterlik inanç düzeyleri, cinsiyetlerine göre anlamlı bir farklılık göstermiştir. Söz konusu araştırmada erkek öğretmen adaylarının öz-yeterlik inanç düzeyleri, kadın öğretmen adaylarına göre daha yüksek çıkmıştır.

Tablo 3'teki verilere göre, katılımcıların mesleki öz-yeterlik inançlarının yaş gruplarına göre anlamlı bir farklılık göstermediği söylenebilir $(\mathrm{p}<0,05)$. Yani, katılımcıların yaş grupları mesleki

Tablo 2. Öz-Yeterlik İnançlarının Cinsiyete Göre Karşılaştırılması

\begin{tabular}{llllll}
\hline Öz yeterlik & Cinsiyet & $N$ & Ortalama & Standart sapma & $t$ \\
\hline Öğrenci katılımı & Erkek & 55 & 52,56 & 14.772 & 1.131 \\
\cline { 2 - 5 } & Kadın & 48 & 49,42 & 13.265 & .399 \\
\hline Öğretim stratejileri & Erkek & 55 & 54,84 & 15.894 & 14.108 \\
\hline & Kadın & 48 & 53,65 & 15.865 & .677 \\
\hline Sınıf yönetimi & Erkek & 55 & 54,09 & 14.346 & .745 \\
\hline Genel & Kadın & 48 & 52,06 & 45.314 \\
\hline
\end{tabular}


Tablo 3. Öz-yeterlik İnançlarının Yaş Gruplarına Göre Karşılaştırılması

\begin{tabular}{|c|c|c|c|c|c|}
\hline Öz-yeterlik & Yaş grubu & $N$ & Ortalama & Standart sapma & $t$ \\
\hline \multirow[t]{2}{*}{ Öğrenci katııımı } & 40 yaş veya altı & 63 & 51,86 & 10.867 & .615 \\
\hline & 40 yaş üstü & 40 & 49,90 & 18.181 & \\
\hline \multirow[t]{2}{*}{ Öğretim stratejileri } & 40 yaş veya altı & 63 & 54,48 & 11.980 & .149 \\
\hline & 40 yaş üstü & 40 & 53,98 & 19.034 & \\
\hline \multirow[t]{2}{*}{ Sınıf yönetimi } & 40 yaş veya altı & 63 & 52,98 & 11.895 & -.122 \\
\hline & 40 yaş üstü & 40 & 53,40 & 19.344 & \\
\hline \multirow[t]{2}{*}{ Genel } & 40 yaş veya altı & 63 & 159,32 & 33.160 & .209 \\
\hline & 40 yaş üstü & 40 & 157,28 & 55.890 & \\
\hline
\end{tabular}

öz-yeterlik inanç düzeylerinde önemli bir etkiye sahip değildir. Bununla birlikte, ortalama değerler dikkate alındığında öğrenci katılımı, öğretim stratejileri ve sınıf yönetimi boyutları için özyeterlik inancının hem 40 yaş ve altı hem de 40 yaş üstü öğretmenlerde oldukça yeterli düzeyinde olduğu söylenebilir. Bu sonuç, Koç'un (2013) araştırmasındaki yaş değişkeninin öğretmenlerin mesleki öz-yeterlik inanç düzeyinde bıraktığı etki düzeyi açısından benzerlik göstermektedir.

Tablo 4'teki veriler dikkate alındığında katılımcıların mesleki öz-yeterlik inançlarının hizmet süresine göre anlamlı bir farklılık göstermediğ $i$ söylenebilir $(\mathrm{p}<0,05)$. Yani, katılımcıların hizmet süresi mesleki öz-yeterlik inanç düzeylerinde önemli bir etkiye sahip değildir. Bununla birlikte, ortalama değerler dikkate alındığında hizmet süresi ne olursa olsun, öğrenci katılımı, öğretim stratejileri ve sınıf yönetimi boyutları için özyeterliklerin oldukça yeterli düzeyinde olduğu söylenebilir.

Her bir demografik değişken için puanların düzeylerini görmek üzere aşağıda verilen grafik incelenebilir.

Tablo 4. Öz-Yeterlik İnançlarının Hizmet Süresine Göre Karşılaştırılması

\begin{tabular}{|c|c|c|c|c|c|}
\hline Öz-yeterlik & Hizmet süresi & $N$ & Ortalama & Standart sapma & $F$ \\
\hline \multirow[t]{3}{*}{ Öğrenci katııımı } & 10 yıldan az & 59 & 51,80 & 10.693 & .565 \\
\hline & $10-19$ yıl & 11 & 53,45 & 10.940 & \\
\hline & 20 yıl veya daha fazla & 33 & 49,06 & 19.567 & \\
\hline \multirow[t]{3}{*}{ Öğretim stratejileri } & 10 yıldan az & 59 & 54,34 & 11.638 & .661 \\
\hline & $10-19$ yıl & 11 & 58,73 & 12.240 & \\
\hline & 20 yıl veya daha fazla & 33 & 52,70 & 20.447 & \\
\hline \multirow[t]{3}{*}{ Sınıf yönetimi } & 10 yıldan az & 59 & 52,76 & 11.500 & .805 \\
\hline & $10-19$ yıl & 11 & 58,55 & 12.573 & \\
\hline & 20 yıl veya daha fazla & 33 & 52,03 & 20.728 & \\
\hline \multirow[t]{3}{*}{ Genel } & 10 yıldan az & 59 & 158,90 & 32.134 & .636 \\
\hline & 10-19 yıl & 11 & 170,73 & 34.549 & \\
\hline & 20 yıl veya daha fazla & 33 & 153,79 & 60.179 & \\
\hline
\end{tabular}




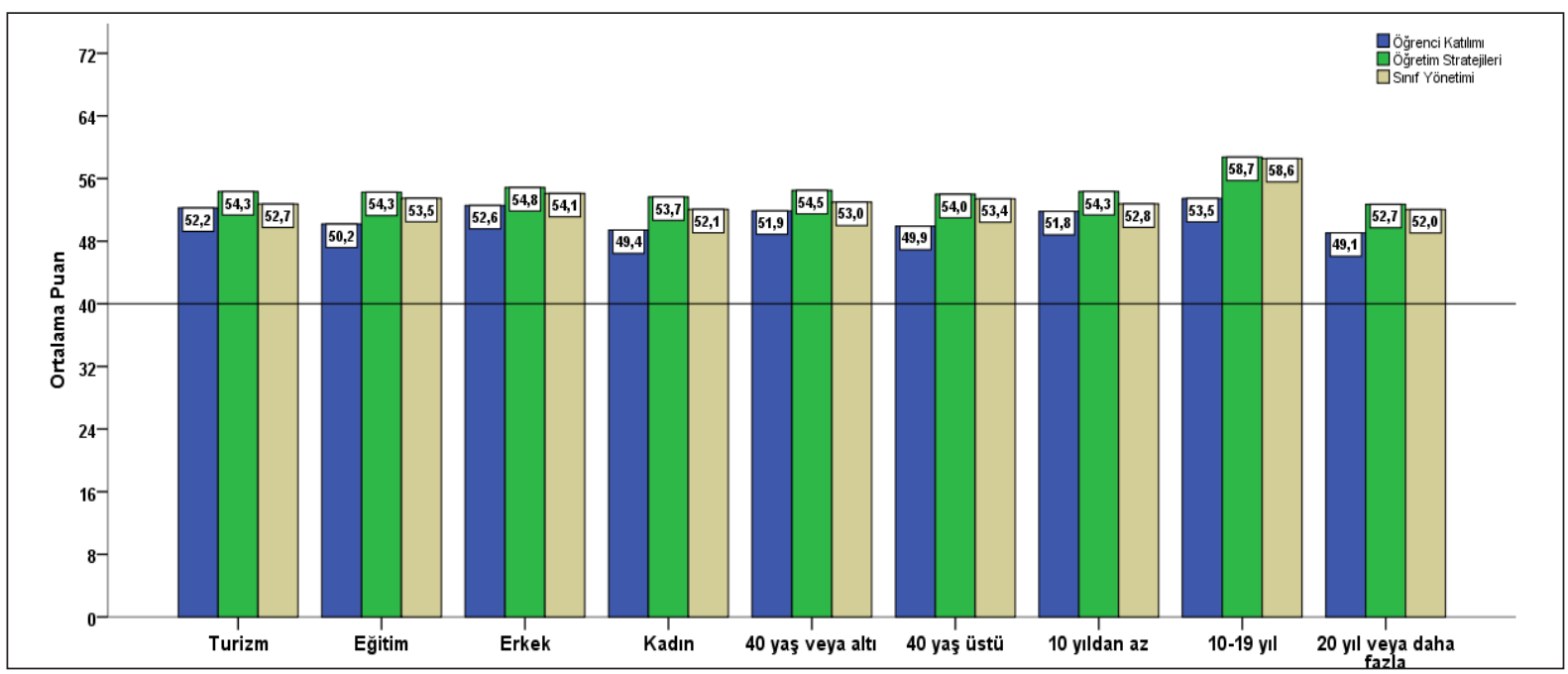

Şekil 2. Öz-yeterlik inancının düzeyi ve beklenen kararın bir fonksiyonu olarak bireyde oluşan davranışsal ve duygusal tepki türleri (Bandura 1982).

Şekil 2'de görüldüğü gibi 10-19 yıl hizmet süresine sahip katılımcılarda, mesleki öz-yeterlik inanç düzeyleri en yüksek değerine ulaşırken, 20 yıl veya daha fazla hizmet süresine sahip katılımcılarda en düşük değerine ulaşmaktadır.

Öğretmenlerin mesleki öz-yeterlik inanç düzeyiyle, hizmet süresi değişkeni arasında anlamlı farklılıkların rastlandığı çalışmalar mevcuttur. Aslan ve Kalkan (2018) yaptıkları araştırmada, hizmet süresi 16-20 yıl olan öğretmenlerin özyeterlik inanç düzeylerinin, beş yıl ve daha az olan meslektaşlarına kıyasla daha yüksek çıktığını tespit etmişlerdir.

\section{SONUÇ}

Bu çalışmada, amaca yönelik olarak eski ve yeni sistemde yetişen turizm öğretmenlerinin mesleğe yönelik öz-yeterlik inanç düzeyleri; öğrenci katılımı, öğretim stratejileri ve sınıf yönetimi boyutları Türkçeye uyarlanmış bir ölçekle incelenmiştir. Araştırmada ortaya çıkan en temel sonuç, katılımcıların eğitim sistemi ayırmaksızın kendilerini oldukça düzeyinde yeterli bulmalarıdır. Literatür incelemesinde turizm dışı farklı bölümlerde yapılan araştırmalarda benzer bir sonuç görülebilir. Aytaç'ın (2018) okul öncesi ve sınıf öğretmenleri üzerinde yapmış olduğu araştırmada mesleki öz-yeterlik inanç düzeyini yüksek bulduğu çalışması, bu araştırmadan elde edilen so- nuçlarla benzerlik göstermektedir. Aslan ve Kalkan (2018) Matematik ve Fen, Sosyal, Güzel Sanatlar ve Spor bölümlerindeki öğretmenlere yönelik yaptıkları araştırmada mesleki öz-yeterlik inanç düzeylerinde anlamlı bir farklılık çıkmamış ve tüm katılımcıların öz-yeterlik düzeyleri yüksek bulunmuştur. Bununla birlikte Matematik ve Fen Bilimleri bölümündeki katılımcıların öğrenci katılımı ve öğretim stratejileri boyutları; Güzel Sanatlar ve Spor bölümündeki katılımcıların ise sınıf yönetimi boyutunda kendilerini daha yeterli buldukları ortaya çıkmıştır.

$\mathrm{Bu}$ araştırmada, eski ve yeni sistemde yetişen turizm öğretmenleri ayırım yapmaksızın kendilerini mesleki olarak yeterli görmeleri pedagojik eğitimi açısından önemli bir noktaya işaret edebilir. Her iki sistemde öğrencilere hizmete dayalı ortamda yetişme olanağının sunulması ve kendilerini turizm eğitim sisteminde geliştirme potansiyeline sahip olmaları, muhtemelen mesleki özyeterlik inançlarının yüksek düzeyde oluşmasını etkilemektedir. Turizm eğitim sisteminde uygulanan zorunlu staj stratejisi, öğrenciler için bu sistemde kaliteli etkinliklerin düzenlenmesi ve günümüze kadar üniversitelerdeki öğretim üyelerinin donanımlı ve nitelikli olması, muhtemelen olumsuz etkilerini ortadan kaldırmada fayda sağladığı düşünülebilir. Açılanan etkilerin dikkate alınması, turizm eğitim sisteminin devamlılığını sağlamada faydalı olabilir. 
Araştırmanın, eski ve yeni turizm eğitim sisteminde yetişen öğretmenlerin mesleki öz-yeterlik inançlarıyla kişisel değişkenleri arasındaki ilişkiye yönelik sonuçlar da bulunmaktadır. Buna göre, her iki gruptan oluşan katılımcıların cinsiyetleri ile mesleki öz-yeterlik inançları arasında anlamlı bir ilişkiye rastlanmamaktadır. İlgili yazında bu sonucu destekleyen araştırmaya (Karabacak 2014) rastlanırken, desteklemeyenler de (Ünlü vd. 2017) bulunmaktadır. Katılımcıların mesleki açıdan cinsiyet ayırmaksızın kendilerini oldukça yeterli bulmaları, güven duygusunun gelişmesinde her iki sistemin iyi olduğunun kanıtı olabilir. Kadınların ve erkeklerin turizm bölümlerini isteyerek seçmeleri ve okumayı tercih etmeleri bu sonucun ortaya çıkmasında etkili olduğu düşünebilir.

Yaş ve hizmet süresi değişkenleri bakımından katılımcıların mesleki öz-yeterlik inançlarının oldukça yüksek çıkması, yeni turizm eğitim sistemini iki farklı yönden değerlendirmeye yol açabilir. Birinci değerlendirmede; yeni sistemin öğrenci yetiştirmede oldukça başarılı olduğu algısı yaratılabilir. Bu değerlendirmeye göre öğrencilerin eğitim aldıkları yeni sistemin yapısı; anlama, irdeleme, beceri gibi boyutların iyi gelişmesine yönelik düzenlenmiş olduğu fikrini ortaya çıkarabilmektedir. Böyle bir durumda yeni sistemde yetişenlerin problemleri çözmede, doğru geri bildirim vermede ve uygun stratejiler uygulamada oldukça başarılı olduğu anlamına gelebilir. Sonuçlara bu açıdan bakıldığında yeni turizm eğitim sisteminin başarılı olduğuna inanılabilir. Bu sistemde yetişenler, ilerleyen zamanda, yaş ve tecrübelerinin artmasıyla daha başarılı olacakları anlamına gelebilir.

Fakat araştırmadan elde edilen sonuçlar farklı bir bakış açısıyla da değerlendirilebilir. Yaş ve hizmet süresi daha az olan katılımcıların mesleki öz-yeterlik inançlarının yüksek olması, yeni turizm sisteminin yapısında çok yüksek benlik saygısı olan bireylerin yetişmesinin belirtisi de olabilir.

Bir eğitim sisteminde yetiştirilecek bireylerin, içten denetimli, yüksek öz-yeterlik ve yüksek benlik saygısına sahip olması için onları yetiştirecek eğitimcilerin de bu özelliklere sahip olmaları gerekmektedir (Arıcak 1995). Bu nedenle, turizm öğrencilerinin modeli olan öğretmenlerin benlik saygı düzeylerinin de ölçülmesi yararlı olabilir. Turizm öğretmenlerinin dış ve iç denetim odaklılık (Rotter 1989) düzeylerini tespit etmek, turizm eğitim sisteminde nitelikli öğretmenlerin ve sektöre kaliteli elemanların yetiştirilmesine katk1 sağlayabilir. Türkiye 2023 eğitim vizyonunda, pedagojik formasyon eğitiminin çağdaş bir yaklaşımla lisansüstü derecesine dayalı olarak yapılandırılması kararlaştırılmıştır. Bu vizyonun gerçekleşmesi ve turizm eğitim sisteminde yetişen öğretmenlerin aidiyet duygusunun güçlenmesi için lisansüstü ders müfredatının hazırlanmasinda, eğitim konusunda tecrübeli turizm akademisyenlerinin görüşlerinin alması önerilmektedir.

\section{KAYNAKÇA}

Abazoğlu, İ., Yıldırım, O. ve Yıldızhan, Y. (2016). Geçmişten Günümüze Türk Eğitim Sisteminde Öğretmen Yetiştirme, Uluslararası Türk Ĕ̆itim Bilimleri Dergisi, 4 (6): 143160 .

Arıcak, T. O. (1995). Üniversite Öğrencilerinde Saldırganlık, Benlik Saygısı ve Denetim Odağı İlişkisi. (Basılmamış Yüksek Lisans Tezi). İstanbul: Marmara Üniversitesi, Eğitim Bilimleri Ana Bilim Dalı.

Aslan, M. ve Kalkan, H. (2018). Öğretmenlerin Öz-yeterlik Algılarının Analizi, Bingöl Üniversitesi Sosyal Bilimler Enstitüsü Dergisi, 8 (16): 477- 493.

Aytaç, A. (2018). Öğretmenlerin Öz-yeterlik Algılarının Çeşitli Değişkenlere Göre İncelenmesi, Academy Journal of Educational Sciences, 2 (1): 29-41.

Bakaç, E. ve Özen, R. (2017). Pedagojik Formasyon Öğrencilerinin Öğretmenlik Mesleğine Yönelik Öz-yeterlik Inançları ile Tutumları Arasındaki İlişki, Kastamonu Eğitim Dergisi, 25 (4): 1389-1404.

Bandura, A. (1977). Self-efficacy: Toward a Unifying Theory of Behavior Al Change, Psychological Review, 84 (2): 191-215.

Bandura, A. (1982). Self-efficacy Mechanism in Human Agency, American Psychologist, 37 (2): 122-147.

Bandura, A. (1995). Self-Efficacy in Changing Societies. New York: Cambridge University Press.

Binbaşıŏlu, C. (1995). Türkiye'de Eğitim Bilimleri Tarihi. İstanbul: Milli Eğitim Basımevi.

Çocuk, H. E., Yokuş, G. ve Tanrıseven, I. (2015). Pedagojik Formasyon Öğrencilerinin Öğretmenliğe İlişkin ÖzYeterlik ve Metaforik Alg1ları: Mersin Üniversitesi Örneği, Mustafa Kemal Üniversitesi Sosyal Bilimler Enstitüsü Dergisi, 12 (32): 373-387.

Çapa, Y., Çakıroğlu, J. ve Sarıkaya, H. (2005). The Development and Validation of a Turkish Version of The Teachers' Sense of Efficacy Scale, Education and Science, 30 (137): 74-81. 
Dadandı, I., Kalyon, A. ve Yazıcı, H. (2016). Eğitim Fakültesinde Öğrenim Gören ve Pedagojik Formasyon Eğitimi Alan Öğretmen Adaylarının Öz-Yeterlik İnançları, Kayg1 Düzeyleri ve Öğretmenlik Mesleğine Karşı Tutumlar1, Bayburt Eğitim Fakültesi Dergisi, 11 (1): 253-269.

Dellinger, A. B., Bobbett, J. J., Olivier, D. F. ve Ellet, C. D. (2008). Measuring Teachers' Self-Efficacy beliefs: Development and Use of the TEBS-Self, Teaching and Teacher Education, 24 (3): 751-766.

Demirtaş, H., Cömert, M. ve Özer, N. (2011). Öğretmen Adaylarının Öz-yeterlik İnançları ve Öğretmenlik Mesleğine İlişkin Tutumları, Eğitim ve Bilim, 36 (159): 96-111.

Elkatmış, M., Demirbaş M. ve Ertuğrul, N. (2013). Eğitim Fakültesi Öğrencileri ile Formasyon Eğitimi Alan Fen Edebiyat Fakültesi Öğrencilerinin Öğretmenlik Mesleğine Yönelik Öz-Yeterlik İnançları, Pegem Ĕ̆itim ve Öğretim Dergisi, 3 (3): 41-50.

Erkuş, A. (2007). Ölçek Geliştirme ve Uyarlama Çalışmalarında Karşılaşılan Sorunlar, Türk Psikoloji Bülteni, 13 (40): 17- 25.

Filiz, B. ve Duranli, M. (2019). The Views of Pre-Service Teachers at an Internship High School on Pedagogical Formation Program in Turkey, European Journal of Educational Research, 8 (2): 395-407.

Goddard, R., Hoy, W. K. ve Hoy, A. W. (2004). Collective Efficacy Beliefs: Theoretical Developments, Empirical Evidence, Andfuture Directions, Educational Researcher, 33 (3): 3-13.

Gurol, M., Türkan, A. ve Som, İ. (2018). Pedagojik Formasyon Sertifika Programının Değerlendirilmesi, Elektronik Sosyal Bilimler Dergisi, 17 (65): 103-122.

Hacıoğlu, N., Kaşlı, M, Şahin, S. ve Tetik, N. (2008). Türkiye'de Turizm Ĕ̆itimi. Ankara: Detay Yayıncılık.

Kahraman, Ü. ve Çelik, K. (2019). Eğitim Fakültesi Formasyon Öğrencilerinin Öz-Yeterlik İnançları ile Mesleki Kaygıları Arasındaki İlişki, Pamukkale Üniversitesi Ĕğitim Fakültesi Dergisi, 45: 353-375.

Karabacak, M. (2014). Ankara İli Genel Liselerinde Görev Yapan Öğretmenlerin Özerklik Algıları ile Özyeterlik Algıları Arasındaki İlişki. (Basılmamış Yüksek Lisans Tezi). Ankara: Ankara Üniversitesi, Sosyal Bilimleri Ana Bilim Dalı.
Koç, C. (2013). Sınıf Öğgretmenlerinin Öz-Yeterlik Algıları ve Yapılandırmacı Öğrenme Ortamı Oluşturma Becerilerinin İncelenmesi, Hacettepe Üniversitesi Ĕ̆itim Fakültesi Dergisi, (1): 240-255.

Kozak, N. (2000). Hasan Olalı: Kısa Yaşam Öyküsü ve Tespit Edilebilen Eserleri ile Yönettiği Tezlerin Bibliyografyası Üzerine Bazı Gözlemler, Anatolia: Turizm Araştırmaları Dergisi, (11): 9-21.

Mishra, P. ve Koehler, M. J. (2006). Technological Pedagogical Content Knowledge: A Framework for Teacher Knowledge, Teachers College Record, 8 (6): 1017-1054.

Olalı, H. (1982). Turizm Politikası ve Planlaması. İzmir: Ege Üniversitesi Matbaası.

Resmî Gazete, (2009). Bakanlar Kurulu Kararı, 2/11/2009 tarihli ve 2009/15546 sayıli, $h$ ttp://www.resmigazete.gov.tr/ eskiler/2009/11/20091113-4.htm, Erişim tarihi: 6 Ağustos 2019.

Rotter, J. B. (1989) Internal Versus External Control of Reinforcement: A Case History of A Variable, American Psychologist, 45 (4): 489-493.

Shulman, L.S. (1986). Those Who Understand: Knowledge Growth in Teaching, Educational Researcher, 15 (2): 4-14.

Taşkın, Ç. Ş. ve Hacıömeroğlu, G. (2010). Öğretmen ÖzYeterlik İnanç Ölçeğinin Türkçeye Uyarlanması ve S1nıf Öğretmeni Adaylarının Öz-Yeterlik İnançları, Dokuz Eylül Üniversitesi Buca Ĕ̆itim Fakültesi Dergisi, 27, 63-75.

Tschannen-Moran, M. ve Woolfolk-Hoy, A. (2001). Teacher Efficacy: Capturing an Elusive Construct, Teaching and Teacher Education, 17 (2): 783-805.

TÜROB, (2018). Türkiye Otelciler Birliği, http://www.turob. com/tr/istatistikler/unwto-2017-turizm-barometresi, Erişim tarihi: 2 Nisan 2019.

Ünlü, İ., Kaşkaya, A. ve Kızılkaya, M. F. (2017). Sosyal Bilgiler Öğretmen Adaylarının Öz-Yeterlik İnançlarının Çeşitli Değişkenler Açısından İncelenmesi, Kırşehir Eğitim Fakültesi Dergisi, 18 (2): 651-667.

Yıldırım, I. ve Vural, O. F. (2014). Türkiye'de Öğretmen Yetiştirme ve Pedagojik Formasyon Sorunu, Journal of Teacher Education and Educators, 3 (1): 73-90. 


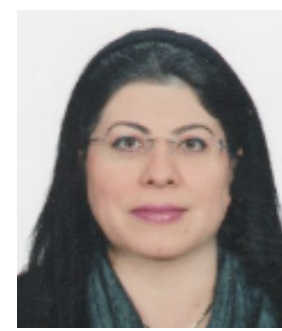

\section{Azize HASSAN}

Gazi Üniversitesi Mesleki Eğitim Fakültesi Turizm İşletmeciliği ve Otelcilik Eğitimi Bölümü’nden mezun oldu (1985). Yüksek lisans derecesini Gazi Üniversitesi Sosyal Bilimler Enstitüsü Üretim Yönetimi ve Pazarlama Programı'ndan (1989), doktora derecesini de İstanbul Üniversitesi Sosyal Bilimler Enstitüsü Turizm Programı́ndan aldı (1993). Gazi Üniversitesi Mesleki Eğitim Fakültesi Turizm İşletmeciliği ve Otelcilik Eğitimi Bölümü’nde Araştırma Görevlisi olarak çalışmaya başladı (1986). Sonrasında Profesör olarak görevine devam etti (2004). Gazi Üniversitesi'nin bölünmesi ile Ankara Hacı Bayram Veli Üniversitesi, Turizm Fakültesi, Turizm İşletmeciliği Bölümü'nde Profesör olarak görev yapmaktadır (2018-devam ediyor). Temel çalışma alanları, turizm eğitimi, turizm işletmelerinde pazarlamadır.

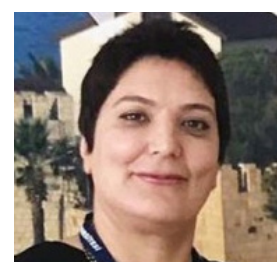

\section{Feriyal FARHADi}

Tebriz Üniversitesi Matematik Dalı'nda eğitimini tamamladı. Yüksek lisans derecesini Gazi Üniversitesi'nden Turizm İşletmeciliği Dalı'nda aldı (2012). Gazi Üniversitesi'nde Turizm İşletmeciliği Dalı́nda doktora eğitimine devam etmektedir. Bilimsel ve sanatsal bakışın harmanlanmasıyla, turizm alanında araştırmalarını yürütmeyi tercih etmektedir. Temel çalışma alanlarl; cittaslow, çevre yönetimi, sürdürülebilirlik, gastronomi ve el sanatlarıdır. 